\section{Collodin with New Owner}

Deardow \& Adams Ltd. has acquired $100 \%$ of the shares of Klebstoffwerke Collodin GmbH. Collodin, based in Frankfurt am Main, Germany, was founded in 1875 and manufactures environmentally friendly solvent-free adhesives. The main application areas are labelling, packaging and paper, as well as for automotive and other technical applications.

Beardow \& Adams, based in Milton-Keynes (UK), is one of the leading worldwide producers of hotmelt adhesives. The company also has manufacturing operations in Sweden, Spain and the USA.

Collodin and Beardow \& Adams have been working together as business partners for 25 years. For Collodin, the worldwide presence of the Beardow \& Adams group offers the opportunity of expanding international activities in its core business. Beardow \& Adams is enhancing its presence in Germany, the most important European market for adhesives.

The development and production of liquid adhesives will remain in Frankfurt. Collodin assures its customers that they will continue to receive good service and the contact persons will remain the same.

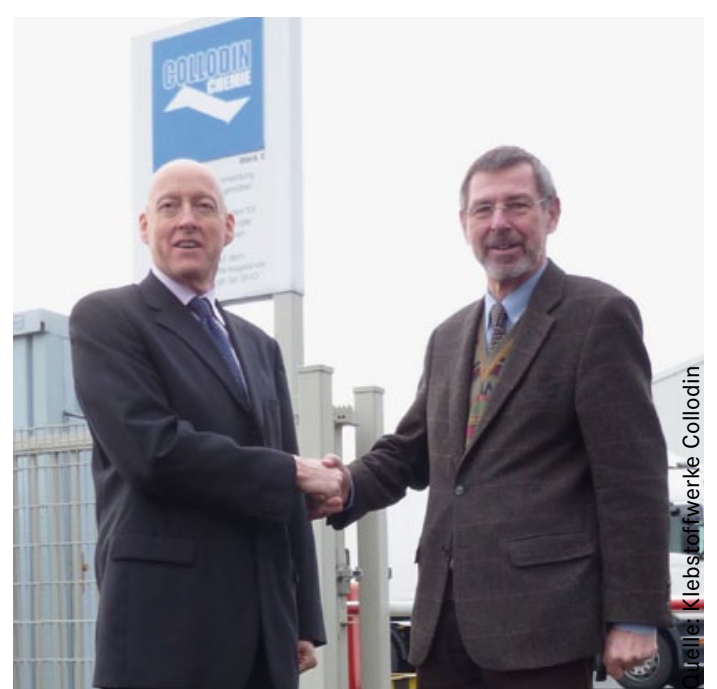

Nick Beardow (left), Sales and Marketing Director of the Beardow \& Adams group, and Paul Joseph Nauth, former owner of Klebstoffwerke Collodin, are convinced that both companies will be made stronger by the acquisition

\title{
Proteins as a High-Performance Adhesive?
}

Dr Markus Valtiner, group leader at the Max-Planck-Institut für Eisenforschung (MPIE) and his American colleague Professor Scott Shell from the University of Santa Barbara (California) have been awarded a valuable grant by the Materials World Network.

V altiner and Shell will receive around half a million euros for a period of three years to allow them to improve the functions of proteins in such a way that they can be used in biosensors, drug manufacturing, tis- sue scaffolds, adhesives and bonding agents. The joint research project combines theory and experimentation. Markus Valtiner is responsible for the experimental side of the project and is investigating the bond between pro-

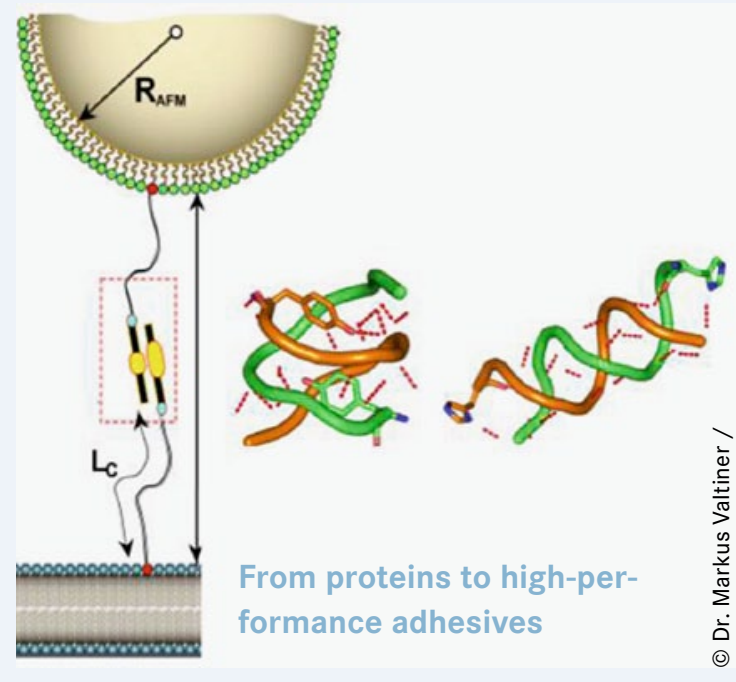

By directly measuring and simulating the interactions between individual proteins and between proteins and surfaces, it is possible to understand the interactions at a molecular level and therefore to make use of them in new technologies teins and solid-liquid interfaces with an atomic force microscope. Scott Shell is examining the molecular structures using computer simulation. If the ambitious research project is successful, it could result in the development of a new generation of biocompatible, environmentally friendly and sustainable super-adhesives.

The members of the Materials World Network include the German Research Foundation, the US National Science Foundation and other European funding organisations. They are working together to promote cooperation in the field of materials research between $\mathrm{Eu}^{-}$ rope and the United States. As the projects that are receiving funding are in competition with national research programmes, only particularly outstanding projects with total funding of three million euros will receive support. This year, only 20 projects worldwide were awarded grants. 